Christa D. Ventling

Sensitivity Training during Pregnancy: Key to Bonding and Possible Prevention of Neurosis of the Child? 
Bibliographic information of Die Deutsche Nationalbibliothek (The German Library) The Deutsche Nationalbibliothek lists this publication in the Deutsche Nationalbibliografie; detailed bibliographic data are available at http://dnb.d-nb.de.

2007 Psychosozial-Verlag GmbH \& Co. KG, Gießen, Germany info@psychosozial-verlag.de www.psychosozial-verlag.de

\section{(C) $(\mathcal{D Q} \Theta$}

This work is licensed under the Creative Commons Attribution-NonCommercialNoDerivatives 4.0 International License (CC BY-NC-ND 4.0). This license allows private use and unmodified distribution, but prohibits editing and commercial use (further information can be found at: https://creativecommons.org/licenses/by-nc-nd/4.0/). The terms of the Creative Commons licence only apply to the original material. The reuse of material from other sources (marked with a reference) such as charts, illustrations, photos and text extracts may require further permission for use from the respective copyrights holder.

Cover image: Theo van Doesburg: Heroische Bewegung (Heroic Movement), 1916 Draft design: Atelier Warminski, Büdingen

https://doi.org/10.30820/0743-4804-2007-17

ISBN (PDF-E-Book) 978-3-8379-6887-3

ISBN (Print) 978-3-89806-704-1

ISSN (Online) 2747-8882 · ISSN (Print) 0743-4804 


\title{
Sensitivity Training during Pregnancy: Key to Bonding and Possible Prevention of Neurosis of the Child?
}

\author{
Christa D. Ventling
}

\section{Summary}

The prime importance of the quality of mother-child bonding has been known for many years among psychotherapists; however, this is not common knowledge for most mothers-to-be. Thus a pregnant client is a chance and a challenge for a body psychotherapist: 1 . We can assist the mother-to-be to form a deep bonding with the baby before birth already by educating her about the neurobiological changes occurring during pregnancy and the expected degree of development of the infant at birth. 2. We can offer special awareness exercises (described here in detail) which improve perception of all senses (seeing, hearing, touching and smelling) and thus sharpen the mother-to-be's sensitivity for her environment, especially for the signals the baby will send out. The work described here aims to help the pregnant client to tune into the body language of the baby as a prerequisite for a deep and loving bonding. It could also be a preventive measure for a later neurosis of the child. Two short case vignettes will illustrate the approach.

Key Words: Pregnant clients - sensitivity training - awareness exercises - newborn signals and body language - bonding quality.

Historically the awareness of the necessity of a mother-infant bonding for survival of the child goes back over 200 years, yet only for the past 50 years do we recognize the importance of the quality of this bonding. Whatever happens at the very beginning of life outside the uterus, sets the stage for the future personality structure of the child. 
We know probably only a fraction of possible disturbing factors and we are still guessing retrospectively when we see a neurotic or depressed client coming for psychotherapy, what the beginning of her or his babyhood could have been like.

How to raise a child in a way that he will grow up to be a happy, healthy, mentally and emotionally well balanced human being is probably on every mother's mind nowadays and also a constant worry. Does she possess the necessary background information? Can we psychotherapists who after all have accumulated a precious amount of knowledge on the subject of mother-infant relationship, can we/ should we not be obliged to inform and educate, at least for some part of therapy? Centuries of suffering for both babies and mothers preceded the incredibly long process that ultimately led to our present concepts of the importance of the quality of the mother-child bonding as predicting the form and direction into which the child's personality and character structure will develop.

Most mothers (or fathers) who come to us for psychotherapy are not aware of the real importance of this early basis in life - but they are bound to find out when they make contact with their own inner child. And many mothers-to-be are fearful about the forthcoming life with a baby for various personal reasons. From the time I saw a pregnant client filled with fear of not being able to love the baby I have been thinking hard about the best way to work with pregnant clients which would instill love for the unborn and confidence for life with baby later on.

The two vignettes below are purposely short and much abbreviated. They are only meant to provide an explanation for how I developed the idea that therapies with pregnant clients should - depending on the status of knowledge of the client - also include some basic information about neurobiological changes during pregnancy and especially at the time of birth. The emphasis here is on finding ways to secure the bonding between mother and baby; not on analyzing the character structure of the client or going into detailed analysis of transferences or on giving an accurate account of the therapeutic process. Such details would go beyond the frame of this article. In both psychotherapies related here, I or better we, the client and myself, had less than 9 
months to work towards the primary goal i.e.,. to help the mother gain sufficient self-confidence to establish a trusting secure bonding with the new baby regardless of his gender.

I am aware that I chose a rather unconventional way of doing body psychotherapy e.g. to mix in an occasional bit of teaching or »dispensing " knowledge when adequate with proper psychoanalytical body work. Yet the good result obtained in the first therapy encouraged me to try it again a second time. The so-called sensitivity training, explained further below is of course no proof that it could prevent a neurosis in the future but it certainly had an increasing effect on the mother's level of awareness in general and especially in the immediate peri- and postnatal time period. It is hoped that readers might be stimulated to also try what I did.

Jane, 28-years old, married for 3 years to an ex-Olympic champion, was beaten by her husband on several occasions so brutally as to require hospitalization. The couple had a 2-year old girl much attached to her father. This was the reason why Jane hesitated to seek a divorce and with this ambivalence came into therapy for help. Bioenergetic body work helped her getting in touch with her repressed feelings. The sado-masochistic marital relationship had a precedent: Jane's father also beat up his children. Jane had learned long ago to stoically bear the physical pain of these beatings, but after she gained the insight that her present situation repeated her childhood experiences and after she rediscovered her real feelings, she came to the conclusion that she no longer needed any of this and filed for divorce. During the following two years the discarded husband made numerous attempts to win her back, a stressful time also in therapy, but she managed to remain firm and obtained the divorce. Shortly thereafter she found herself pregnant - her ex-husband's revenge had been a violation. Jane was in a new dilemma: to keep the baby or to go for an abortion. She opted for the baby. Now we worked on her fears, that the baby would resemble the father, would display a similar character structure etc. and that she would never be able to love this child.

I discovered that Jane, although she had gone through one pregnancy already, did not really know much about pregnancy or a newborn. Our sessions from now on included information on the biology 
of pregnancy (as described further on), on the development of the baby, on his abilities at birth, his body language, his signals etc. and the more she learned about this, the more curious and loving towards this as yet unborn and unknown baby she became. With this client I developed the awareness exercises as outlined below which she experienced as a completely new world. She said it felt like her body had opened up in every respect to let in sights and sounds never experienced like this before. Eventually the pregnancy came to an end and Jane gave birth to a boy. She gazed into his eyes, said she saw love and bonded immediately with him. She said that it was all so very different from the birth of her daughter. Her relationship with the boy remained good in spite of his occasional temper tantrums. Jane took him with her to therapy sessions for about half a year and we often had live demonstrations of previously theoretical points. We ended the therapy when her boy was 2 years old. A couple of years later I met Jane by chance and learned that she had a loving relationship with a new partner and was very pleased with the way her children developed.

Some time after the termination of this therapy another woman, whom I will call Paula, with an almost identical history came into therapy, except that she was already pregnant with her second albeit unwanted child, also result of a sexual assault by her divorced husband, from whom she had to flee to the "Woman's Shelter « with her little girl in order to protect the child from the beatings of the father. Paula also chose to keep the baby in spite of her worries that it might be a boy and turn out to have inherited the aggressive personality structure of his father. I once said to Paula: »if you can »read « the baby, his bodily and facial expressions, interpret the look of this eyes, you have won half the battle."

With Paula I did repeats of the sensitivity training sessions because she often seemed to "go away «. They helped keep her grounded. She also got curious wanting to know more about the specific neurobiological development of the baby. I therefore included on demand intermittent short bits of psychoeducation. In the end she gave birth to a boy. She said that she loved him at first sight. She also brought the baby along for therapy sessions for the first 6 months. I could see that Paula and her little boy had built up a good and strong bonding. This 
therapy came to an end after a couple of years because Paula moved away due to her job. She still writes me a letter every Christmas and tells me in details about the progress everyone is making in her family.

In the following I will highlight some historical landmarks the knowledge of which I consider crucial for us psychotherapists. Some may be strictly background material for the therapist, others lend themselves to be told to the client.

\section{How the Concept of the Importance of Mother- Child Bonding Developed Historically}

\section{The Medieval Age: Lack of Interest in Children}

The medieval age, writes Barbara Tuchmann (1980) was characterized by a striking comparative absence of interest in children, emotion in relation to them rarely appeared in art or literature or other documentary evidence; half of all children born died before the age of six through lack of care, lack of food or infectious disease and half of all the mothers died sooner or later from childbed fever or other disease. On the whole, babies and young children appear to have been left to survive or die without great concern in the first five or six years. Up to the $13^{\text {th }}$ century it was customary to test the viability of a newborn baby by dipping him into a very cold brook (Hrdy 1999, p. 464). The Catholic Church then actively renounced infanticide - which this dipping custom often was - and as a solution for an unwanted child recommended they donate the child to the Church. How many newborn babies were then dropped at doorsteps of nunneries is a guess. It is left to our fantasy what psychological effect this early rejection and abandonment may have had on the character and history of the survivor. A cruel period indeed which makes us shudder when we read about it. 


\section{The $18^{\text {th }}$ Century: Sudden Interest in Children}

The $18^{\text {th }}$ century, Age of Enlightenment, was characterized by major changes in rational thinking with effects extending into all areas: politics, law, science, religion, art and for us most interesting: education. Now suddenly there was talk of the possibilities of a happy process of the natural unfolding of the character, of learning from observations of nature and from the experience within nature, of the free and uninhibited development of one's own abilities to reach a happy and joyful adulthood. The "Art of Becoming a Human Being" was defined as leading the growing child and young adult to develop a sane, healthy body and mind, a moral character, an intelligent brain, and teaching restraint and self-denial of one's feelings in order to comply with the requested social behavior.

This only would ultimately lead to happiness. These remarks were made by Jean-Jacques Rousseau who describes in his novel "Emile" published in 1762 how he envisions the realistic adaptation of his ideas on child rearing. He says that he would start by convincing the nurse taking care of the baby to take off his diapers as often as possible, as they tended to inhibit a proper growth of the limbs. Then he would convince the mother to nurse the baby instead of giving it to a wet-nurse, because a wet-nurse could possibly hurt the child through being cruel or negligent with the baby or she could win the child's affection which should be directed to the mother as the first source of love and first tie to form an orderly family unit. Nursing would guarantee a stronger and healthier baby.

Rousseau was absolutely right, both from a hygienic and an affectionate viewpoint. While mother's milk is sterile, water, used to dilute cow's milk, in those days was often contaminated. Dysentery was in fact the most common cause of death of small children. Registered rural wet nurses took care of babies in order to make a living, as money meant survival of one's own family; but the life of a stranger's baby did not count, and an emotional attachment to this baby was unthinkable (Hrdy 1999, p.11, 351). Infant mortality soared and death of children was everyday news. Rousseau's plea went unheard, his conclusion that a responsible, loving mother was needed, did not 
get the attention it deserved and thus was forgotten. Although Rousseau was a controversial figure in many ways, I consider him the founding father of the concept that an early close physical relationship between baby and mother is necessary for survival. It is tragic that it took almost 200 more years until the attachment theory of Bowlby proved Rousseau right.

\section{The $20^{\text {th }}$ Century: Wars Provide Insight into the Importance of Mother-Child Bonding}

The $20^{\text {th }}$ century was a century of repeated wars and drama with uncountable children becoming orphaned. Small children ended up in institutions, older ones often struggled by themselves. As a result of all these wars orphanages all over were overcrowded and understaffed and in deplorable conditions.

After 1940 the first of many publications by a number of researchers appeared producing evidence of the traumatizing effects of even short stays, let alone year-long ones in these homes (Durfee \& Wolff 1934; Lowrey 1940; Bender \& Yarnell 1941; Bakwin 1942; Goldfarb 1944, 1947; Dührssen 1958; Spitz 1945, 1946a, 1946b, 1950). Most startling and impressive was a black-and-white silent movie made by the German physician and psychologist René Spitz about children he visited in an orphanage in Mexico, called »Grief: a peril in infancy" (Hrdy 1999, p.395). He became famous with this movie and followed it up with a number of publications (Spitz 1945,1946a, 1946b, 1950) on careful and detailed observations of children in such institutions. Here is what he found:

$>$ separation from the mothers invariably was harmful, even lifethreatening, and the situation got worse with increased length of separation from the mother,

$>$ the lack of loving care, of cuddling, of close physical contact with the nurses plus the problem of undernourishment produced symptoms which included retardation in language comprehension, in muscular skills and in social behavior if the children survived long enough. 
The worst-off children became apathetic, refused contact, refused to eat, made not a sound anymore and finally died like a candle going out, all signs of what Spitz called »anaclitic depression «.

Spitz concluded that regular and maintained physical, sensual and emotional contact between the caretaker and the child was absolutely essential for the formation of a life-sustaining relationship.

Spitz's conclusions formed the basis for the attachment theory of John Bowlby (Bowlby 1951, 1969). Its central premise is this: Infants seek a secure attachment and need a secure attachment base for healthy emotional development. Bowlby thought that this base is best provided by the mother, but caretakers can also be other persons, as long as they are available on a regular basis and maintaining a strong emotional contact and as long as the quality of the attachment is a secure one (Ainsworth \& Wittig 1969, Ainsworth \& Bell 1970, Main 1981, Main \& Solomon 1986). The important point to remember is that it is the infant who actively seeks the attachment.

\section{Bonding as Preventing Neuroses: the State of the Art}

\section{Wilhelm Reich's Utopia}

The question whether it is possible to avoid later neuroses by taking appropriate measures very early on in life was a challenging one for Wilhelm Reich. He founded a center where pregnant women could receive therapeutic care before birth and where they could return to afterwards with their baby. The center was staffed with competent social workers and doctors. Reich also envisioned a journal where the latest research data would be published - this was in 1949, at the time when René Spitz's findings on the orphanage children became known all over. A year later the dream of Reich for his »Children of the Future as he named it came to an end, for a number of reasons, one of them being his demand that the women there should not have any 
»character armoring «, in other words be free of any neurotic trait. His selective search for such perfect women to become perfect mothers with perfect children was far too unrealistic and bound to fail.

\section{Modern Approaches}

Nevertheless the question whether neuroses of adult life can be prevented remains intriguing enough. If we start to look at what time in life one should actually start, the time of birth seems the most logical. And in fact it is a good time. The mother-baby dyad is being formed now if it has not been formed already earlier during pregnancy, mother-baby interactions take place according to the mother's knowhow, her sensitivity, her intuitive feeling for what is going on in the baby and how the baby is affected by the environment. But many unforeseen crisis events can happen at birth or any time thereafter, upsetting the attachment of mother and child and therapeutic repair work becomes necessary. Thus it could be that the birth process is unexpectedly complicated and delivery difficult for the mother and in consequence has an anatomical or psychological effect on the baby or both. Sometimes medication during delivery becomes unavoidable and this influences the baby's emotional and cognitive presence, delaying the bonding process. Or it could be that a happy mother-child dyad is suddenly disrupted due to separation from or loss of the mother. Or the bonding process is disturbed due to unresolved neurotic problems in the mother stemming from her own childhood or going further back to her own insecure, disorganized or avoidant bonding with her mother (Ainsworth \& Bell 1970). Or the young mother must go back to work immediately after birth and childcare is inadequate, the mother worries, gets depressed, is not capable of giving her best in the little time she has available to establish a secure bonding between herself and the child.

Bonding remains the key word and every effort should be made, with the help of the therapist, but also by the mother or caretaker, to keep the quality high. What approaches then for preventing a later disorder in the growing child actually exist? Let me summarize: 


\section{Mother-Infant Dyad}

Daniel Stern $(1998,2000)$ and his coworkers (Stern et al. 2001) did pioneer work in analyzing the interaction of mothers and their babies by taking videos of them in various situations, nursing, playing, etc. Since it is the baby who sends out signals for the mother to respond to, one can determine whether the mother understands the body language of the baby - which is what it is! They stop the video at fractions-of-seconds in intervals and analyze the reactions and expressions of both mother and baby.

This method is ingenious. Not only does the therapist see what could be improved, the mother sees it also and is convinced. With the appropriate coaching or maybe therapy, she can modify her behavior for the better. Micro-video-analysis is fast becoming a method of the future. George Downing, Vita Heinrich, Martin Dornes, Peter Geissler and others are applying it in their work with young mothers and their babies (Downing 1994; Kühntopp \& Heinrich 2001, Downing \& Ziegenhain 2001, Dornes 1992, 2000; Geissler 2006). I think we can look forward to many more papers testifying to the efficacy of this method. The learning effect on the mother has a direct bearing on her behavior towards her baby: Bonding is improved. Consequences of an insecure bonding in childhood are known to lead to split personalities later in life (splitting the feelings off, living from the brain; Rand 1996, Tonella 2000). Munzel (2002) suggested that it could even lay the ground for serious somatic disorders like multiple sclerosis.

A baby, even if he had some bad experiences, can still relatively easily »heal « - in the Piaget sense (1975), because accommodation leads to a new assimilation and vice-versa. The neocortex is still in a phase of continuous biological and neurological growth and so pliable that new structures are continuously laid down over the old ones, modifying them constantly. In summary then, working with mother-baby dyads is a very promising direction and I would predict holds an excellent prognosis! 


\section{Baby}

Eva Reich continued one of the interests of her father Wilhelm Reich with regard to the »unarmored « child, but shifted towards small babies. She developed what is termed »gentle baby massage « or »butterfly massage «. The baby through the physical contact with the hands of his mother feels good, relaxes and tensions disappear. Eva Reich has taught her method to many people and several institutions have sprung up offering »emotional first-aid « to problem babies, notably in Bremen, Berlin and Rome (see Harms 2000, Reich \& Zornanszky 1997, Wendelstadt 1998). The therapist teaches the mother this massage. It is actually based on an old tradition in India from where Francis Leboyer, initiator of the natural childbirth, brought it back and taught it to Eva Reich. How good this method is in terms of preventing neurosis is probably too early to tell as most of the babies treated so far have not yet reached adulthood and to my knowledge no scientific data exist as yet.

\section{Mother-Child Dyad}

How mothers and their preschool children present themselves in play and what conclusions to draw from their interactions in terms of quality of bonding was studied by Jens Kühntopp under the guidance of Vita Heinrich (Kühntopp \& Heinrich 2001). They used some of the bioenergetic exercises modified for children by Halsen (1992, 2001). They not only diagnosed the type of relationship but provided therapy as well. The sessions were recorded on video and played back to the mothers who with the help of the therapists could discuss changes of interaction patterns if necessary. The videos were also presented to neutral therapists, who did not know the mother or her child or anything about them. By answering a questionnaire referring to the scenes on the video, an independent and neutral critical viewpoint leading to suggestions for altering the behavior of the mother towards her child was obtained and could be evaluated statistically. To see herself and her child on video can lead the mother to new in- 
sights and initiate change. This is an excellent method. It could not only be truly preventive in terms of later neurosis, but it entails a scientific approach for research. Having such early data would provide a base line for testing the adult the child has grown into.

\section{Child and Adolescent}

Somewhere during childhood, between the age of the preschooler and the school-age child an invisible line exists, where a neurosis-preventive approach is not possible anymore. Maybe there is maternal deprivation, maybe an unusual behavior pattern has set in. We may have entered the field of early traumatizations leading to neurosis. From here on, instead of prevention we should talk about treatment and healing (von Klitzing et al. 2001, Ventling 2001).

Let us return to the subject of neurosis prevention. What stage is left? Let me come full circle and go back to pregnancy. How much and which information we give or how we give this information about the neurobiological changes during pregnancy, about the development of the fetus, about the birth and the chemical basis for bonding, about the importance of the mother-baby bonding in terms of consequences for the development of the personality and character structure etc. all remains an individual decision for the psychotherapist and depends very much on the curiosity of the client, on her trusting the therapist and last but not least on the bonding between them. It is actually a triad, for the baby whether unborn or born, is very much at the center of attention.

I think that one can do excellent preventive work with pregnant clients, provided one sharpens their awareness for the baby's »language «. Fear of what is about to come, »life with baby « can be a strong deterrent for bonding. As a therapist I feel challenged to turn the client's fear into joy, her ambivalence into tender love and her hesitancy into a warm welcome of the baby. I do this in 3 ways, always spontaneously, when the situation lends itself:

$>$ I inform my client what happens during pregnancy in the mother neurobiologically and what she can expect to happen in the baby. 
> I relate to her what I call the baby's »Starter Kit«.

$>$ I work on her sensory awareness for seeing, hearing, touching and her olfactory sense and thus prepare her for »reading " the baby.

\section{Pregnancy to Birth: Mother and Baby}

\section{Neurobiological Aspects of Pregnancy}

Pregnancy and motherhood forever change a woman (Hrdy 1999, p. 94-95). Pregnancy alters the chemistry of her brain, preparing her for labor and motherhood. The pituitary gland (also called hypophysis) enlarges greatly in size. It produces a large number of different hormones which in turn control the activities of several other endocrine glands. Some of the hormones are of the endorphine type,- the word is derived from endogenous morphine-like -, indicating that they produce a calming, soothing, well-being effect.

One of the best known and best studied of these endorphins is oxytocin. The name is derived from the Greek word okus meaning swift and tocin from tokos meaning birth. Oxytocin as its name indicates makes the pain of childbirth bearable. During pregnancy the number of oxytocin receptors increase greatly in the brain and uterus, getting ready for the birth. When the production of those hormones responsible for maintaining pregnancy stops, this then signals go for oxytocin production and labor is induced. When this is not happening the natural way, synthetic oxytocin is often given intravenously to a woman to initiate contractions.

During the latter part of the pregnancy specific neural pathways are laid out for the accentuation of certain sensory capacities in the mother, such as smell, hearing and also feeling. They enable a mother to be constantly aware of her baby. New mothers can smell better, hear extremely well, most can pick up an irregular breathing of the baby next door and all can hear the baby crying ever so faintly at night which their husbands rarely can! Many new mothers feel their 
baby so much as part of themselves, even while physically away from him, that seconds before the infant begins to whimper, needle-like sensations can be felt in the nipples and warm milk leaks out.

\section{The »Starter Kit « of the Baby}

What can a newborn baby do already at birth? He can smell, he can differentiate sweet from sour and already favors sweet (like the milk of his mother); he can grasp and differentiate cloth from skin and he favors skin - that of the mother; he can hear and locate sounds, like the heartbeat of his mother and when placed on her belly, he will attempt to root toward her left nipple. He recognizes the voice of his mother, he recognizes his father by his smell due to the pheromones the father has emitted and the mother has breathed in all during pregnancy and thus passed onto the fetus - and he can see clearly the face of his mother while nursing, though not yet in color or in three dimensions. He can express hunger, pain, and the wish for contact with his voice and a few gestures. That is the baby's "Starter Kit« as I would like to call it. The infant is biologically prepared to engage in a dialogue with his mother and to form a firm bonding. But is his mother ready? Not necessarily.

\section{Bonding in Neurobiological Terms}

We know from research with rodent and primate mothers that affiliate behavior has a chemical basis and that it involves oxytocin (Panksett et al. 1985). A monkey mother whose brain receptors to oxytocin were blocked with a specific antagonist, made fewer overtures toward her infant and was less likely to put her face near the baby's. She tolerated the offspring alright but it was left to the infant to cling for dear life (Keverne, 1995). We conclude from this and from similar experiments that loving feelings are not automatic, but are promoted and that the promoting factor is oxytocin.

In humans the endogenous production of oxytocin after birth is di- 
rectly related to the sucking of the newborn. When the baby is suckling, oxytocin levels rise sharply and stimulate the synthesis of prolactin. Prolactin needs to reach a certain concentration in order to induce milk production. This takes about three days. Sometimes oxytocin production is delayed (Robson \& Koumar 1980), when e.g. medication was necessary during the birth process. All of this explains why perinatal bonding is not love at first sight (Shore 1997), but a process whereby strong feelings of attachment to the baby grow within days, when the mother holds the baby close, makes skin contact and gazes at her little darling. The process of attachment continues over weeks following birth.

Bowlby 40 years ago suggested that vision is central to the establishment of a primary attachment. He was partially right, chemically speaking at least. When the mother gazes happily into the eyes of her baby, oxytocin - we know this today - is produced in her brain (Shore 1997). The happiness seen in the mother's eyes by the baby in turn triggers high levels of oxytocin in the child's growing brain and he will glow with happiness. This shows also clearly that while sucking of the baby is wonderful it is not a prerequisite to bonding, as the production of oxytocin also works through other sources. A woman who adopts a baby and thus fulfills her long-kept wish will also relay her deeply felt happiness to the baby. The chemical reaction behind it is the same as with a biological mother.

Now of course mother or caretaker and baby are not just looking into each others eyes, they are using the voice and gestures in their dialogue, not to forget the physical contact. These early social events are circulatory in nature -Spitz spoke about a »duet « and Stern about a »dance « (1998) - and they are imprinted into the biological structures that are maturing during the brain growth spurt that occurs during the first two years of life. The organization of a hierarchical regulatory system in the prefrontal areas of the right hemisphere of the neocortex is of particular importance, for here the basis is formed for social functioning later on in life. While these structures are laid down the brain continuously grows - in fact it has reached $70 \%$ of adult size within one year (Aiello 1992, Aiello \& Wheeler 1995) and full size within two years (Himwich 1975). 
The first two years of life are thus crucial indeed. Traumatic experiences within this time lead to bad or faulty imprints, lack of experience to no imprint at all. Again we know from animal experiments that lack of stimulation of specific nerves leads to their irreversible degeneration. When e.g. an eye of a newborn rat is taped closed for several weeks, no visual stimuli reach the visual nerve of this eye and it degenerates. The same is true if one closes an ear of a newborn rat with paraffin - he will never hear with this ear because the auditory nerve degenerates in the absence of auditory stimuli. We assume this pattern to be valid for all nerves: Nervous impulses reach specific areas of the cortex and lay down the structure corresponding to the stimulus. This is the neurobiological equivalent of what Piaget (1975) called »assimilation « and »accommodation «.

Furthermore we have good reasons to assume that the findings from animal research are valid also for human babies. For lack of bonding - as we know now - occurs through lack of skin contact, lack of sensual stimulation. It can lead to a shutting down of the development of the emotional (right) hemisphere of the brain in favor of the thinking (left) hemisphere which matures later than the right one. In other words this could be the beginning of the mind/body split. Poorly bonded babies will grow into insecure adults, driven to figure out how to get by, how to cope and how to control situations (Rand 1996). They live their life from their heads and prefer to ignore their emotional center, which could throw them out of control.

\section{Possible Roles of the Therapist}

Since early events of life have such an inordinate influence on literally everything that follows, what can we as body-psychotherapists contribute? I would say, several aspects are possible and this independent of whether the therapist is a man or woman.

$>$ We can establish a caring, mothering relationship with a pregnant client, a sort of bonding on a different level. This is key to help her with her anxieties about the growing fetus, his signs of life 
after the $16^{\text {th }}$ week of pregnancy, the birth and the relationship with her child thereafter.

-We can educate her. Infants need mothers to keep them warm, safe, stimulated, clean, fed, and most important, to communicate tenderly and responsively their commitment to go on caring. Caretakers need not be the mother, or even one person, but they should always be the same so as to provide constancy. We can point out to our client that good bonding takes place when there is skin contact and stimulation of all senses. We can tell her about the need of the baby to bond and how he is trying to achieve this. We can teach her about the "Starter Kit « of the baby and about what she as a new mother is offering and help her »read « the signals of the baby. The better she is prepared for this, the easier is the establishment of bonding. Telling a mother-to-be that all she has to do is to carefully read the signals of the baby and respond, not initiate the »duet « or »dance« takes a lot of pressure off of her.

$>$ We teach her that quality, not quantity of time is important. Attachment does not mean enchaining the mother and does not require a 24 -hour presence of the mother or caretaker. We must be careful that we do not inflict guilt feelings on working mothers who preferentially give quality time after dinner and on week-ends.

- We can help her increase her perception so that her awareness for the baby's expressions is increased with exercises which increase perception and sharpen awareness in general and which are easily done during a therapeutic session. They are even fun to do and as I was told by my pregnant clients most helpful. (For more details see Ventling 2001).

\section{Awareness Exercises}

For all the exercises - and I only do one type per session - I first give directions, but then I let the client explore in silence for a while, then we talk about her experience. As a start I ask the client to find a comfortable position, to relax, maybe to place her hands over her belly 
and breathe normally. Enough time (several minutes) should be allowed and further exploring by the client should be encouraged.

\section{Awareness of Color}

I ask my client to let her eyes wander about the room and out of the window and to note in her mind everything she sees which has the color pink. It is a good idea to specify a color which is not predominant in the session room. After a while of silence I ask her to repeat her »walk « with eyes closed. And after some more silence I ask her to tell me what all she noticed, whether the »walk « with closed eyes was different from the one with open eyes and, if yes, in what respect, whether there were images emerging having something to do with the color pink or memories etc. The client may want to know which colors the baby can differentiate and at what age.

\section{Awareness of Shape}

This exercise is done exactly alike except that I choose a common shape, e.g. everything round. Clients are often shocked to find that they speak about a certain object as being round, because they know it is round, yet from the position they are looking it does not appear to be round. This then leads us usually into a discussion about what and how the baby sees things.

\section{Awareness of Noise}

For this exercise a not very sound-proof session room is of advantage. The client is asked to notice anything she hears, again first with open eyes and then with closed eyes, each time for about 5 minutes. Noises can be in the room or coming from the outside or from inside the client's belly. The surprise here is usually the notable difference between perceiving noises with closed eyes and with open eyes, of locat- 
ing noises, again of combining hearing with knowing and it may lead to a discussion about what all the baby can discriminate by hearing.

\section{Awareness of Odor}

I ask the client still sitting, to start out recording the odor of the room, through deep breathing, with eyes open and also closed, to notice a possible difference. I then ask her to walk around the room and feel free to put her nose to the furniture, the desktop, the window or the rug, for example, always with eyes open and then closed, sniffing and recording. Finally I ask her to smell her own skin on her arms, her hands, maybe her hair. Clients are usually amazed how many odors can be differentiated and how they are related to specific memories. Again they usually want to know what the baby can smell.

\section{Awareness of Touch}

I ask the client to touch with just one finger or two various regions or parts of her hand, forearm, elbow, upper arm, neck, face, calves etc. again once with eyes open and once with eyes closed, to stay quite long on one area, to apply pressure maybe, to compare and note the differences. Later we talk about the experience. The difference in sensitivity of the various areas is readily noticed and it raises curiosity about what the baby can feel.

\section{Conclusions}

To have a pregnant client in therapy is in my mind an excellent opportunity to promote future bonding of the mother-to-be with her baby, integrating facts about pregnancy and development of the baby into the therapeutic process. This creates an emotional climate very much suited to receive the newborn baby with love and form a strong bonding. Furthermore perception exercises tend to bring our pregnant clients 
to a greater sensitivity and awareness of the body language of the baby and provide a good basis for being able to »read « his signals.

For the two described cases here this modified type of bioenergetic therapy seems to have resulted in a very positive effect. Both women were extremely fearful of men after what they had experienced during their short marriages and also full of rage. During therapy some of these strong negative feelings could be released and the danger that they might turn them against their unborn babies was much diminished. One patient managed to enter a new and happy relationship with a man who cared very much for her children and thus was a good substitute father. The other patient had retained her mistrust toward men at the time she had to move. I gathered that her traumatization from her husband would have required much more therapy. However, the relationship of these two mothers with their boys turned out to be a good one and this I consider a very important result of the type of therapy I provided. Whether my approach could actually be neurosispreventing, cannot be answered at the present time and must be left for future researchers.

\section{Bibliography}

Aiello L C (1992) Human body size and energy. In: James S, Martin R and Pilbeam D (eds) The Cambridge Encyclopedia of Human Evolution, p.45. Cambridge University Press, Cambridge.

Aiello L C, Wheeler P (1995) The expansive tissue hypothesis. Current Anthropology 36: 199-221.

Ainsworth M D, Wittig B A (1969) Attachment and exploratory behaviour in oneyear olds in a strange situation. In: Foss B M (ed) Determinants of Infant Behaviour 4. Methuen, London.

Ainsworth M D, Bell S M (1970) Attachment, exploration and separation: Illustrated by the behavior of one-year-olds in a strange situation. Child Development 41: $49-67$.

Bakwin H (1942) Loneliness in Infants. American Journal of Diseases of Children 63: 30 ff. Bender L, Yarnell H (1941) An Observation Nursery: A Study of 250 Children in the Psychiatric Division of Bellevue Hospital. American Journal of Psychiatry 97: $1158 \mathrm{ff}$.

Bowlby J (1951) Maternal Care and Mental Health. Bulletin Mental Health Organization 3: $355 \mathrm{ff}$. 
Bowlby J (1969) Attachment and loss. Vol. 1: Attachment. Basic Books, New York. Dornes M (1992) Der kompetente Säugling. Die präverbale Entwicklung des Menschen. Fischer, Frankfurt a. M.

Dornes M (2000) Die emotionale Welt des Kindes. Fischer, Frankfurt a.M.

Downing G (1994) The Body and the Word. Routledge, New York.

Downing G, Ziegenhain U (2001) Besonderheiten der Beratung und Therapie bei jugendlichen Müttern und ihren Säuglingen - Die Bedeutung von Bindungstheorie und videogestützter Intervention. In: G J Suess, H Scheuerer-Englisch \& WK P Pfeifer (Hrsg) Bindungstheorie und Familiendynamik. Psychosozial Verlag, Giessen.

Dührssen A (1958) Heimkinder und Pflegekinder in ihrer Entwicklung. Verlag für Medizinische Psychologie, Göttingen

Durfee H, Wolff K (1934) Anstaltspflege und Entwicklung im ersten Lebensjahr. Zeitschr.f. Kinderforschung 42: $273 \mathrm{ff}$.

Geissler P (2006) Videomikroanalyse der frühen Interaktion: Ein wissenschaftliches Instrument auf dem Weg zu einer modernen körper-psychotherapeutischen Theoriebildung. Psychoanalyse \& Körper 9 (2) 67-87.

Goldfarb W (1944) Effects of Early Institutional Care on Adolescent Personality: Rorschach Data. American Journal of Orthopsychiatry 14: $441 \mathrm{ff}$.

Goldfarb W (1947) Variations in Adolescent Adjustment of Institution-reared Children. American Journal of Orthopsychiatry 17: $449 \mathrm{ff}$.

Halsen A (1992) Bioenergetic Work with Children: Experiences from a Child Psychiatric Unit. Journal of the International Institute for Bioenergetic Analysis 5 (1): 30-44. (Reprinted in: Ventling C D (ed.) Childhood Psychotherapy: A Bioenergetic Approach. Karger, Basel. 2001.

Harms T (2000). Auf die Welt gekommen - die neuen Babytheorien. Leutner, Berlin. Himwich W A (1975) Forging a link between basic and clinical research: developing brain. Biological Psychiatry 10: 125-139.

Hrdy Bluffer S (1999) Mother Nature. Pantheon Books, New York.

Keverne E B (1995) Neurochemical changes accompanying the reproductive process: Their significance for maternal care in primates and other mammals. In: Pryce C R, Martin R D and Skuse D (eds) Motherhood in Humans and Nonhuman Primates. Karger, Basel, pp. 69-77.

Kühntopp J, Heinrich V (2001) Bioenergetic Duos - Uncovering Deficits in MotherChild Relationships. In: Ventling C D (ed) Childhood Psychotherapy: A Bioenergetic Approach. Karger, Basel, pp.23-31.

Lowrey L G (1940) Personality Distortion and Early Institutional Care. American Journal of Orthopsychiatry 10: $76 \mathrm{ff}$.

Main M (1981) Avoidance in the service of attachment: a working paper. In: Immelmann K, Barlow G W, Petrinovich L and Main M (eds) Behavioral Development: The Bielefeld Interdisciplinary Project. Cambridge University Press, Cambridge.

Main M, Solomon J (1986) Discovery of a new, insecure-disorganized / disoriented 
attachment pattern. In: Brazelton B and Yogman M (eds) Affective Development in Infancy. Ablex, Norwood NJ, pp. 95-124.

Munzel M. (2002) Multiple Sclerosis: The Psychosomatic Consequence of Unsuccessful Bonding. A Viewpoint. In: Ventling C D (ed) Body Psychotherapy in Progressive and Chronic Disorders. Karger, Basel, pp. 35-48.

Panksett J, Siviy S M and Normansell L A (1985) Brain opioids and social emotions. In: Reite M and Field T (eds) The psychobiology of Attachment and Separation. Academic Press, Orlando FL, pp. 3-49.

Piaget J (1975) Das Erwachen der Intelligenz beim Kinde (Orig.1936: La naissance de l'intelligence chez l’enfant) Klett, Stuttgart.

Rand M L (1996) As it was in the beginning: The significance of infant bonding in the development of self and relationships. Journal of Child and Youth Care 10 (4): 1-8.

Reich E, Zornanszky E (1997) Lebensenergie durch sanfte Bioenergetik. Kösel, München.

Robson K M and Koumar R (1980) Delayed onset of maternal affection after childbirth. British Journal of Psychiatry 136: 347-353.

Shore A N (1997) Interdisciplinary Developmental Research as a Source of Clinical Models. In: Moskowitz M, Monk C, Kaye C and Ellman S (eds) The Neurobiological and Developmental Basis for Psychotherapeutic Intervention, pp. 1-71.

Spitz R A (1945) Hospitalism. An Inquiry into the Genesis of Psychiatric Conditions in Early Childhood. The Psychoanalytic Study of the Child 1: $53 \mathrm{ff}$.

Spitz R A (1946a) Hospitalism. A Follow-Up Report. The Psychoanalytic Study of the Child 2: $113 \mathrm{ff}$.

Spitz R A (1946b) Anaclitic Depression. The Psychoanalytic Study of the Child 2: $313 \mathrm{ff}$.

Spitz R A (1950) Anxiety in Infancy: A Study of its Manifestation in its First Year of Life. International Journal of Psychoanalysis 31: $138 \mathrm{ff}$.

Stern D (1998) Mutterschaftskonstellation. Klett-Cotta, Stuttgart.

Stern D (2000) The relevance of empirical infant research for psychoanalytic theory and practice. Zeitschrift für psychoanalytische Theorie und Praxis 15 (4) 467-483.

Stern D, Bruschweiler-Stern N, Harrison A M, Lyons R K, Morgan A C, Nahum J P, Sander L, Tronick E Z (2001) The process of therapeutic change involving implicit knowledge: Some implications of developmental observations for adult psychotherapy. Med Psychol 51 (3-4): 147-152.

Tonella, G. (2000) The Interactive Self. Bioenergetic Analysis 11(2) 25-43.

Tuchmann B W (1980) A Distant Mirror. Penguin Books, London.

von Klitzing K, Tyson P, Bürgin D (eds) (2001) Psychoanalysis in Childhood and Adolescence. Karger, Basel.

Ventling C D (2001) Birth and Bonding: To be or Not to Be. In: Ventling C D (ed) Childhood Psychotherapy: A Bioenergetic Approach. Karger, Basel, pp. .9-18.

Wendelstadt S (1998) Emotional first-aid - healing a birth trauma. Bioenergetic Analysis 9 (1) 85-96. 


\section{About the Author}

Christa D. Ventling is a clinical psychologist (Lic.phil.), a certified bioenergetic therapist (CBT 1995), a member of the teaching faculty and supervisor of the Swiss Society for Bioenergetic Analysis and Therapy (SGBAT), presently working in private practice in Basel. Prior to becoming a bioenergetic psychotherapist, she had been engaged for over 25 years in various medical-biological research projects, following her original studies of chemistry and biochemistry (DPhil Oxford University). Her interest in research has continued and includes two major studies on the efficacy of BAT as well as several single case studies notably of chronic or incurable diseases. For her investigation on the efficacy of BAT in 2002 she received the First Prize for the best research awarded by the US Association for Body Psychotherapy (usabp). She is editor/author of »Childhood Psychotherapy: A Bioenergetic Approach « and of "Body Psychotherapy in Progressive and Chronic Disorders", published in 2001 resp. 2002 by Karger, Basel.

Dr. phil. Christa D.Ventling

Holbeinstrasse 65

CH-4051 Basel

Switzerland

E-Mail: c.vent@bluewin.ch 